\title{
Monitoring and auditing the local socio-economic and environmental impacts of the early stage construction of Hinkley Point C Nuclear Power Station, UK
}

\author{
John Glasson, Bridget Durning, Martin Broderick and Kellie Welch \\ Impacts Assessment Unit, School of Built Environment, Oxford Brookes University
}

\begin{abstract}
Major projects, in sectors such as transport, energy, minerals and water, have long life cycles and can have significant local and regional environmental and socio-economic impacts. The impacts of the construction stage can be particularly damaging, if not managed well. Environmental Impact Assessment (EIA) seeks to anticipate such impacts, mitigate adverse and enhance positive impacts through design innovations and associated conditions. However, the approach is only as good as the implementation of such innovations and conditions. The issue of monitoring and auditing of actual, as against predicted, impacts is an Achilles heel in the planning and assessment process. Hinkley Point $\mathrm{C}$ (HPC) nuclear power station in the UK is currently one of the largest construction projects in Europe. A recent study of the live project provides a unique insight into the actual local impacts of the early construction years, and appropriate methods of assessment. It identifies KPIs, examines monitoring data, and audits findings against the predictions. The results show varying performance across key impact sectors. Explanations of differences are set out, together with recommendations for improving monitoring and auditing practice.
\end{abstract}

Key words: Monitoring and auditing the impacts of major projects, Hinkley Point $\mathrm{C}$ nuclear power station construction.

\section{Introduction}

A major Achilles heel of EIA as practised in many countries has been a focus on the period before the project authorisation decision which, at worst, can lead to a 'build it and forget it' approach (Culhane 1993). Yet many major projects, in sectors such as transport, energy, minerals, waste and water, have long life cycles. EIA should not stop at the decision; it should be an adaptive process to achieve good socio-economic and environmental management over the life of the project. Many years ago, Holling (1978) recommended an adaptive EIA process to cope with decision-making under uncertainty. He advocated periodic reviews of the EIA through a project's lifecycle, with a 'predict, monitor and manage approach'. This means including follow-up monitoring and auditing as essential elements in the EIA process (Arts et al 2001; Morrison-Saunders and Arts 2004; IAPA 2005; Bjorkland 2013; Jones and Fischer 2016; Pinto et al 2019; Glasson and Therivel 2019). Such follow-up can provide evidence about the accuracy of EIA predictions, the implementation of conditions, and indeed the utility of particular monitoring processes, which in turn can help to improve the management of projects through their life cycle and provide evidence-based learning for future projects.

This article uses the case of new nuclear build (NNB) projects. These are some of the largest current, and often particularly contentious, construction projects in the world. The country focus is on the UK where the last NNB project to be completed was Sizewell B, in East Anglia, in 1995. Uniquely for that project, a team from the Impact Assessment Unit (IAU) at Oxford Brookes University monitored and audited the local community impacts of the seven-year construction programme (Glasson and Chadwick 1995; Chadwick and Glasson 1999). Subsequently, the data from the Sizewell B study has provided valuable evidence for the recent planning of new NNB in the UK. However, that evidence is now over 25 years old; NNB projects, socio-economic conditions and planning and assessment methods change 
and evolve. There is a need for new monitoring and auditing research to provide better data for current project management and future learning for NNB projects and indeed for other major projects.

The New Nuclear Local Authorities Group (NNLAG) in the UK recognised this need. NNLAG is a Local Government Association Special Interest Group, consisting of fifteen Local Authorities that already host or are likely to host NNB projects. NNLAG's purpose is to share knowledge, information and best practice regarding new nuclear, and to use such information in discussion with key stakeholders, including Central Government and major developers. Hinkley Point C NNB in Somerset in South West England, the first NNB since Sizewell B, began main construction in 2016, and provides the opportunity for new monitoring and auditing research, the results of which could flow into subsequent developments -- the next one planned being Sizewell C in Suffolk.

A team from the IAU of Oxford Brookes University undertook the research in 2018 and 2019. It was a relatively short study of about 9 months. It covered the first two and half years of a twelve-year HPC construction programme, and is before peak construction. HPC is currently one of the largest construction projects in Europe. It is a $£ 20$ bn project, with a current workforce of over 5000, and rising. The project is located in the district of West Somerset and Taunton Deane in a rural location of Somerset in Southwest England. The Environmental Statement (ES) for the project identified a number of key issues, including for example the impacts of a large incoming workforce on traffic, accommodation, and on services such as health and policing. Examples of mitigation measures include the provision of Park and Ride facilities on the nearby M5 motorway to reduce car vehicle impacts, a new bypass of the village of Cannington, and two purpose built substantial construction worker accommodation campuses, with health facilities, with one on site and the other in the local town of Bridgwater (Figure $1)$.

Figure 1: HPC location

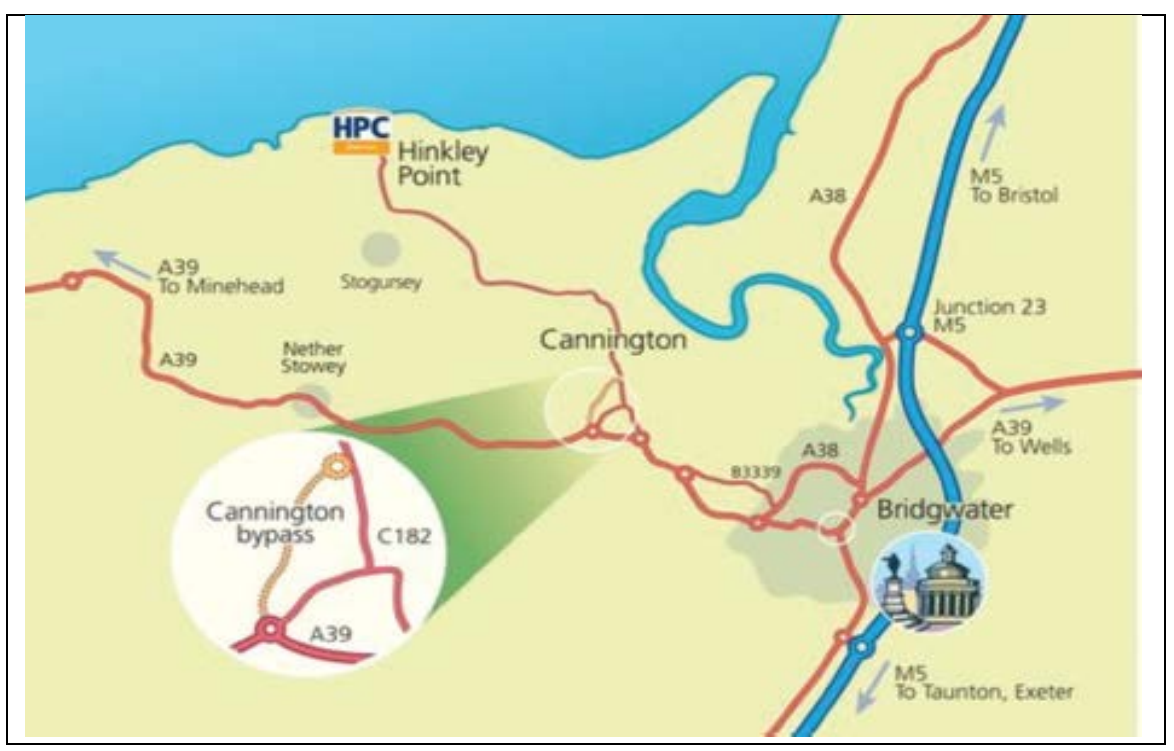

Source: EDF Energy HPC website

This article explores opportunities and issues associated with monitoring and auditing in planning and assessment processes for major projects, before setting out the research questions and research methodology. Further sections provide summaries of some of the key findings, and seek to clarify the factors behind the variations in performance across a range of impact sectors. The article then draws some implications for monitoring, auditing and management practice in the spirit of an adaptive EIA 
process, and in light of recent EU and UK regulations now requiring such monitoring (EU 2014, 2017; HMG 2017). Whilst the focus is on NNB projects, the approach and findings will be relevant and of interest to researchers and key stakeholders involved in many other types of major projects.

\section{Monitoring and auditing issues}

Of key importance for the management of the local and regional impacts of a project are the effectiveness of the monitoring and auditing structures and procedures put in place for the project and their operation in practice from various stakeholder perspectives. This has been the subject of some academic debate over the last two decades (see for example Marshall et al 2005; IAPA 2005; Jones and Fischer 2016; Pinto, E et al 2019), plus some example of developer and consultancy good practice (see for example Glasson 2005; Highways England 2016). Drawing on this literature, Table 1 sets out some good practice considerations for monitoring and auditing. This includes, for example, the importance of a clear monitoring and auditing programme, with open and regular reporting, and a partnership between the various stakeholders involved (eg developer, local authority and local community), with information openly shared, and independently verified.

\section{Why Monitor and Audit? Some motivating factors for stakeholders}

\section{Key activities in EIA follow-up}

Monitoring

Auditing/Evaluation

Management

Communication

\author{
Form of EIA follow- \\ up \\ Description
} Monitoring for
conformance
Monitoring for compliance post- decision

Evaluation for future knowledge

Management for future consents and licences

Management for liability avoidance

Communication for consent closure predecision

Stakeholder communication, and participation
The collection of data and comparison with standards, predictions or expectations that provide proof of technological, management or operational control against a specific consent requirement or voluntary mitigation measure

Monitoring and audit activities that are developed through environmental management frameworks to demonstrate how the collective body of consent conditions or voluntary mitigation measures will be enacted and complied with

The appraisal of the actual impact or implemented mitigation and enhancement measures with predictions and conditions for one development, that can provide learning, addressing areas of impact encountered in future developmental EIA

Monitoring and evaluation activities during EIA that facilitate operational or environmental permitting in the current and subsequent stages of the development's life cycle

Monitoring and evaluation activities arising from EIA that offset future risk of liability or compensation issues

Anticipatory proposals that detail management, monitoring or evaluation proposals submitted pre-decision, their objective being to foreclose concerns and to positively increase the likelihood of the development being granted statutory consent

Activities integrated within the EIA process that inform and empower stakeholders or communities, enhancing the relationship between the developer and such interested parties to better manage concerns and impact issues

Source: adapted from Marshall (2005)

How to monitor? There should be a clear monitoring and auditing programme, ideally set out in the project ES, which has clear objectives, temporal and spatial controls, an adequate duration (e.g. covering the main 
stages of the project's implementation), practical methodologies, sufficient funding, clear responsibilities and open and regular reporting.

Who monitors? Ideally there should be a partnership between the various stakeholders; for example, the collection of information may involve the developer, local authority and local community. Who manages the monitoring system and the resultant information is also important. The information collected needs to be stored, analysed and ideally openly shared between relevant participants in the EIA process. Independent analysis and verification of information enhances the credibility of the monitoring and auditing process.

Mandatory or discretionary? Whilst there are some good national examples of mandatory monitoring, in many countries, including in the UK, this has not been the case. However, in the EU this changed under the amended Directive of 2014 (EU 2014). EU Guidance (EU 2017) now sets out mandatory monitoring requirements for both project construction and operation. Data collection and and evaluation activities should be frequent enough to provide relevant information, but not so frequent as to be a burden to those involved. Monitoring results should be audited by relevant authorities.

Table 1: Some good practice considerations for monitoring and auditing

Notwithstanding the benefits of monitoring and auditing set out in Table 1, good practice is limited. Some key barriers include lack of mandatory requirement, the costs involved, unenforced legislation, and little learning incentive for developers with one-off projects. Whilst there are examples of follow up requirements in some EU states, practice can be poorly developed (Runhaar et al 2013). In the UK there has been little evidence of good practice, especially for the vital construction stage of major projects, as noted in a recent report by the National Infrastructure Projects Association (NIPA 2019): 'There has been little research on the results of the effectiveness of the environmental monitoring and management during the construction of NSIPs (Nationally Significant Infrastructure Projects)...... The sharing of the findings of monitoring could improve decision making, could provide reassurance to communities for whom the anticipation of impact can be more daunting than the reality, and enable developers to improve environmental management practices.'

However, even with a fair mandatory wind, as now in the EU, good practice monitoring and auditing faces a number of operational problems. These were set out by Chadwick and Glasson (1999) in relation to the earlier monitoring study of the socio-economic impacts of the construction stage of Sizewell B, which was the last nuclear power station to be built in the UK and which became fully operational in 1995 (Table 2).

- Nature of impact predictions: many Environmental Statements (ESs) contain few testable predictions; also many predictions are vague, imprecise and qualitative

- Project modifications: post-ES project modifications may invalidate many predictions

- Monitoring data: data and techniques may be inadequate for auditing purposes; baseline data may be insufficient; and data collected and provided by the project proponent may give rise to fears of possible bias in content

- Comprehensiveness: many auditing studies are concerned only with certain types of impacts (eg. biophysical but not socio-economic; construction stage but not operational stage impacts) and are only partial project EIA audits.

- Clarity: few published auditing studies are explicit about the evaluation criteria used to establish prediction accuracy

- Interpretation: few auditing studies pay attention to the underlying causes of predictive errors 
Table 2: Some operational problems in monitoring and auditing studies for major projects Source: adapted from Chadwick and Glasson (1999).

\section{Research approach: questions, objectives and methods}

Using the case study of Hinkley Point $\mathrm{C}$, the research seeks to address three inter-related questions, with a particular focus on the first question. To what extent: (i) do the EIA predictions for the impacts of early NNB construction match the actual impacts (prediction audit); (ii) are the conditions attached to the development permission met in practice (compliance audit); and (iii) are the procedures used by key stakeholders for monitoring and auditing effective and appropriate (process audit)? It is important to learn from the actual experience of NNB construction and operation. Resources spent on baseline studies and predictions may be of little value unless there is some way of testing the predictions and determining whether mitigation and enhancement measures are appropriately applied. Such learning involves both impact monitoring (the identification and measurement of actual impacts) and impact auditing (the comparison of actual with predicted impacts) (Glasson, $\mathrm{J}$ et al 2020).

The research involved a series of stages: setting the research approach and key parameters, monitoring and auditing impacts across socio-economic and biophysical sectors, undertaking contextual studies, drawing overall conclusions, with identification of data and monitoring gaps, and making recommendations for improving practice. Key parameters included for example: a focus on testable predictions, the use of publicly available information to maximise credibility and the auditing of impacts across a range of scales, as included in predictions. Brief contextual studies included a review of the effectiveness of the monitoring structures and procedures put in place for the HPC construction project, and their operation in practice from various stakeholder perspectives. There was also a comparison of those monitoring structures and procedures with those for three other major projects studies: London 2012 Olympics project - legacy; Crossrail - construction nearing completion; and Wylfa Newydd NNB - examination completed.

The research covered six impact sectors: economic development, transport, social and community, accommodation, environmental health and the biophysical environment. For each sector, the research had three main steps:

- Identifying - clarifying strategic issues and obligations; indicators and Key Performance Indicators (KPIs); and key data sources, drawing in particular on the HPC project ES (EDFE 2011) and Development Consent Order (DCO) ${ }^{1}$ (Planning Inspectorate 2013), Section $106^{2}$ and the local authorities' Local Impact Reports (Somerset Local Councils 2012).

- Monitoring - establishing findings, key indicator trends and events over the main construction stage to date, drawing on publicly available information.

- Auditing - assessing degree of accuracy of monitoring findings against predictions and conditions, and explanations of any differences, gaps in monitoring process and future proposals.

The major and lengthy first step in each sector study was the identification of key issues, indicators and KPIs. In some cases, this was complicated with changing KPIs and developer obligations over time. In addition to the information in the ES, DCO etc, there were valuable meetings with representatives of the Somerset local authorities, and staff from the developer, EDFE (Electricite de France Energy). These meetings helped to identify data sources, and issues for investigation in the various sectors; for example, there was a particular local authority concern about the impacts of inmigrant construction workers on the local housing market. 
For the second, monitoring step, the availability of information also varied between, and within, sector studies. Valuable online data sources included the various 'data dashboards' produced by the SocioEconomic Advisory Group and the Transport Review Group, and the minutes of various community fora, all of which were established for HPC construction monitoring. These include the Community Forum, Transport Forum, and Main Site Neighbourhood Forum; they have an independent chair. They include officers of the local councils, the developer, and other stakeholders; are open to members of the public and their minutes are publicly available.

The third, audit step, for each sector seeks to compare actual with predicted impacts for specific indicators and KPIs, to explain any differences between them, to identify gaps in monitoring and to make recommendations for future practice. The audit assessments are the independent findings of the IAU research team, based on publicly available monitoring information. For quantitative information, accurate assessments are estimated as being within a range of $+/-10 \%$ of predictions. The research team applied a simple colour coding (RAG system) for each indicator/KPI, ranging from Dark Green (very accurate/compliant), to Dark Red (very inaccurate/non-compliant). Blue indicates no information available/auditing not possible at the time of the study (Table 3). In some cases, there is a split assessment to reflect a mix of audit outcomes to date.

\begin{tabular}{|l|l|}
\hline $\mathbf{G}$ & $\begin{array}{l}\text { Predictions very accurate with actuals; fully compliant with conditions/obligations } \\
\text { LG }\end{array}$ \\
\hline $\mathbf{A}$ & $\begin{array}{l}\text { Most predictions are good, but with a few topic and/or time gaps, and inaccuracies; largely } \\
\text { compliant }\end{array}$ \\
\hline $\mathbf{O}$ & Prediction inaccuracies/gaps in many areas; very limited compliance \\
\hline $\mathbf{R}$ & Prediction very inaccurate; non-compliant \\
\hline
\end{tabular}

\begin{tabular}{|l|l|}
\hline B & No information available; auditing not possible at the time of the study \\
\hline
\end{tabular}

(NB: letters added to colours for black and white printing)

Table 3: RAG colour coding used in auditing for each sector

\section{Findings - an overview}

Table 4 provides an overview of the audit of the accuracy of actual as against predicted impacts. The findings draw on predictions in the ES and monitoring information on actual impacts from data sources and interviews noted in section 3 . The public availability of a flow of accurate monitoring data is the key to the auditability of impact predictions. The research found the most adequate monitoring information for the transport, and social and community impacts (especially health and community services) sectors. There is also some good information for much of the economic development sector, 
although there are some gaps. There is more fragmented monitoring information for the accommodation sector, and publicly available information is very patchy, and in several cases completely absent, for many of the impact indicators in the environmental health and biophysical environment sectors. As such, in several cases, the available monitoring data proved inadequate to audit ES predictions and the $\mathrm{DCO}^{1 / S 106^{2}}$ requirements and obligations. There may be a variety of reasons for the variations in adequacy of the monitoring data. There are well-developed monitoring systems for some quantitative indicators, such as traffic flows and, for this project, for health and community safety impacts. Other part explanations may be the degree of specificity of project requirements and obligations, and the relative efficiency and organisation of the various monitoring groups involved in the HPC project.

Table 4 shows good performance against predictions for the economic development and transport sectors, and especially for the social and community sector, including health and community safety. There is more mixed performance against predictions for the accommodation sector, with more spatially concentrated construction worker use of private rental accommodation than predicted. The blue colour coding for the environmental health and biophysical environment reflects the absence of publicly available monitoring information at the time of the research. Section 5 provides a more detailed analysis of three of the sectors-- economic development, transport and accommodation. A discussion of the key factors behind variations in performance against predictions and conditions follows in section 6 .

\begin{tabular}{|l|l|l|}
\hline Impact sector & Commentary on actual vs predicted impacts & \multicolumn{1}{|l|}{$\begin{array}{l}\text { Summary RAG } \\
\text { colour coding }\end{array}$} \\
\hline $\begin{array}{l}\text { Economic } \\
\text { development }\end{array}$ & $\begin{array}{l}\text { At the audited pre-peak phase, the project is performing well against } \\
\text { predictions in many impact areas, including local employment } \\
\text { content, training and education, apprenticeships, jobs brokerage, } \\
\text { local supply chain inputs and tourism. Mitigation and enhancement } \\
\text { measures appear to be working well. However, there is some debate } \\
\text { about the actual level of total workforce numbers, set against } \\
\text { predictions, about disaggregated employment impacts (eg. skill types } \\
\text { for local and immigrant workers, opportunities for various under- } \\
\text { represented groups). }\end{array}$ & A \\
\hline Transport & $\begin{array}{l}\text { There is also current good performance against predictions for many } \\
\text { transport indicators. These include the key indicators of mode share } \\
\text { for workforce journey to the main site, with the P\&R bus system } \\
\text { working well, and the Delivery Management System actuals v Heavy } \\
\text { Goods Vehicles limits. However, the car share system, in place in } \\
\text { relation to worker journeys to the P\&R sites, has not been as effective } \\
\text { as expected, and there was the unexpected issue of workforce fly } \\
\text { parking. However, better management appears to be now in hand for } \\
\text { both issues. Delays in the delivery of key transport infrastructure, } \\
\text { including the jetty and P\&R sites, meant that there were more issues } \\
\text { in the early stages of the project. }\end{array}$ & A \\
\hline $\begin{array}{ll}\text { Social and } \\
\text { community }\end{array}$ & $\begin{array}{l}\text { Overall, there is good performance against a number of the impact } \\
\text { indicators. For health, the early provision of the on-site Medical } \\
\text { Campus has provided a high level of medical treatment and advice } \\
\text { for the workforce, taking the pressure off the local NHS services. For } \\
\text { community safety, there appears to be good management of potential } \\
\text { project impacts through a combination of measures, including the } \\
\text { Worker's Code of Conduct, and some additional resourcing of } \\
\text { community liaison and policing, and emergency services. Some } \\
\text { construction impacts affect community wellbeing; the Community } \\
\text { Impacts Mitigation fund provides some compensatory measures. }\end{array}$ & \\
\hline & LG & \\
\hline
\end{tabular}




\begin{tabular}{|c|c|c|c|}
\hline Accommodation & $\begin{array}{l}\text { Assessment of accommodation actuals against predictions is } \\
\text { complicated by differing views of predictions and accommodation } \\
\text { type definitions, and especially by most predictions being for peak } \\
\text { employment (with all campuses assumed then operating at/near } \\
\text { capacity). Actual locations of inmigrant workers are more } \\
\text { geographically concentrated (esp. in the town of Bridgwater) than } \\
\text { predicted, and more in the Private Rented Sector (PRS) tenure } \\
\text { category. There are some useful housing support initiatives. It is } \\
\text { difficult, within the constraints of publicly available data, to identify } \\
\text { inmigrant workforce housing impacts on local vulnerable groups, } \\
\text { although there does not seem to have been to date a noticeable impact } \\
\text { on homelessness in Somerset. }\end{array}$ & $\mathbf{A}$ & \\
\hline $\begin{array}{l}\text { Environmental } \\
\text { health }\end{array}$ & $\begin{array}{l}\text { Unlike the socio-economic impacts, most environmental impacts are } \\
\text { well regulated, with various standards and thresholds, and monitoring } \\
\text { mainly relates to any exceedances of such standards and thresholds. } \\
\text { It is assumed that there is appropriate monitoring for such } \\
\text { environmental health impacts, such as noise and air for HPC } \\
\text { construction, and these are likely within predicted thresholds. } \\
\text { However, the team found little publicly available information to } \\
\text { confirm this, other than a relatively low level of local complaints. It } \\
\text { is unclear how data is being collated between the parties involved } \\
\text { (Councils, EDFE, and Environment Agency) and if the sum of these } \\
\text { add up to more significant impacts on the public. Routes for public } \\
\text { complaints are unclear and not conducive to gain public involvement } \\
\text { or trust. Overall, there is a split colour summary between amber } \\
\text { (mixed adequacy) and blue (no information). }\end{array}$ & $\mathbf{A}$ & B \\
\hline $\begin{array}{l}\text { Biophysical } \\
\text { environment }\end{array}$ & $\begin{array}{l}\text { The key biophysical environmental issues identified are landscape } \\
\text { and visual amenity concerns and mitigation measures; archaeological } \\
\text { and heritage issues; impacts on local terrestrial, coastal and marine } \\
\text { ecology; and flood risk issues. Management plans exist for these } \\
\text { topics, and it is assumed that mitigation and monitoring work is in } \\
\text { hand. However, currently, all the biophysical environmental impact } \\
\text { topics addressed in this research have a blue flag, which indicates that } \\
\text { information is not publicly available or has not been located to date } \\
\text { to complete an audit. As with environmental health, there appears to } \\
\text { be a split regarding storage of information and responsibility for } \\
\text { monitoring. }\end{array}$ & B & \\
\hline
\end{tabular}

Table 4: Audit summary -- of HPC sectors actual impacts against predicted impacts

\section{Findings - some sector examples}

\subsection{Economic development}

The economic development sector focuses on HPC construction employment, skills, and supply chain issues, and on managing impacts on other economic sectors. This is a vital starting point for monitoring and auditing of a range of socio-economic impacts. The extent of local content of construction employment has many local and regional direct and indirect effects. Locally based construction workers already have accommodation, and their families, as relevant, have on-going and established interactions with a wide range of local services, including for example schools, doctors and policing. In contrast, inmigrant workers place new and additional demands on local accommodation and other local services. 
The use of local suppliers can have a multiplier effect on the local economic benefits of the project, but there may also be some potential disbenefits, associated for example with job displacement from local firms, wage inflation, and specific sector impacts, especially on tourism in Somerset. Table 5 summarises some of the findings to date. Figure 2 compares estimated workforce numbers against actual over the early years of the construction workforce curve showing a reasonable, if slightly higher, level of actual with predicted numbers. Figure 3 focuses on the percentage of local recruitment from within the 90-mins Construction Daily Commuting Zone, showing that local content has closely achieved the predictions for the early years. The RAG coding in Table 5 is generally very positive in relation to other aspects of employment, with good recruitment from women, high level of apprenticeships, and transformational educational initiatives for the local area. Similarly, for the supply chain, there is much evidence of good use of local and regional suppliers. Further, potential negative impacts on local tourism appear offset by implementation of various mitigation measures supporting the important Somerset tourism economy. There is also the added bonus for some tourism accommodation providers of much fuller occupancy over the calendar year from take-up by construction workers.

\begin{tabular}{|c|c|c|c|}
\hline Indicator/KPI & Examples of audited impacts & \multicolumn{2}{|c|}{$\begin{array}{l}\text { RAG } \\
\text { Coding }\end{array}$} \\
\hline \multicolumn{4}{|l|}{ Employment } \\
\hline $\begin{array}{l}\text { Overall level of } \\
\text { workforce }\end{array}$ & Actual levels near/above 2012 prediction, but some caveats. & $\mathbf{L G}$ & \\
\hline $\begin{array}{l}\text { Local content: } \\
\text { CDCZ }\end{array}$ & Percentages better than predictions; but missing disaggregated data & G & B \\
\hline $\begin{array}{l}\text { Recruitment from } \\
\text { unemployed }\end{array}$ & At $1 \%$-- well below $8 \%$ target, but context has changed & \multicolumn{2}{|l|}{$\mathbf{R}$} \\
\hline Apprenticeships & $\begin{array}{l}\text { Good, } 433 \text { (April 2019) exceeds DCO target, and on course for } 1000 \\
\text { aspirational target. }\end{array}$ & \multicolumn{2}{|l|}{ G } \\
\hline $\begin{array}{l}\text { Recruitment from } \\
\text { women }\end{array}$ & $19 \%$ female is good for civils work stage of major project & \multicolumn{2}{|l|}{ G } \\
\hline $\begin{array}{l}\text { Training and } \\
\text { educational } \\
\text { initiatives }\end{array}$ & $\begin{array}{l}\text { Wide range of transformational initiatives, underpinned financially by } \\
\text { EDFE, and others. }\end{array}$ & \multicolumn{2}{|l|}{ G } \\
\hline \multicolumn{4}{|l|}{ Supply chain } \\
\hline $\begin{array}{l}\text { Local and regional } \\
\text { supplier } \\
\text { registrations }\end{array}$ & $\begin{array}{l}\text { Good level of registrations. Particularly good local level--well in advance } \\
\text { of } 750 \text { initially anticipated for Somerset }\end{array}$ & \multicolumn{2}{|l|}{ G } \\
\hline $\begin{array}{l}\text { Number and value } \\
\text { of contracts } \\
\text { awarded to } S W \\
\text { region companies }\end{array}$ & $\begin{array}{l}\text { In aggregate, the } £ 982 \mathrm{~m} \text { for the SW supply chain region, and anticipated } \\
\text { another } £ 700 \mathrm{~m} \text {, is well on way to easily exceeding the predicted } £ 1.5 \mathrm{bn} \\
\text { for total construction stage }\end{array}$ & \multicolumn{2}{|l|}{ G } \\
\hline $\begin{array}{l}\text { Potential negative } \\
\text { impacts on local } \\
\text { firms and areas }\end{array}$ & $\begin{array}{l}\text { Difficult to identify as no hard data here. From discussions with Somerset } \\
\text { Chamber of Commerce, the impact is mixed }\end{array}$ & LG & $\mathbf{A}$ \\
\hline $\begin{array}{l}\text { Impacts on tourism } \\
\text { sector in Somerset }\end{array}$ & $\begin{array}{l}\text { Local tourism industry confidence seems high. Mitigation measures, } \\
\text { provided in advance, have helped. There is also the added bonus for some } \\
\text { tourism accommodation providers of much fuller occupancy over the } \\
\text { calendar year. }\end{array}$ & \multicolumn{2}{|l|}{$\mathbf{G}$} \\
\hline
\end{tabular}

Table 5: Some examples of audited employment predictions 
Figure 2: Construction Workforce Labour Demand Curve - Estimated (curves) and Actual (cols) Workforce Numbers to date (Month 0 is taken as mid-2016)

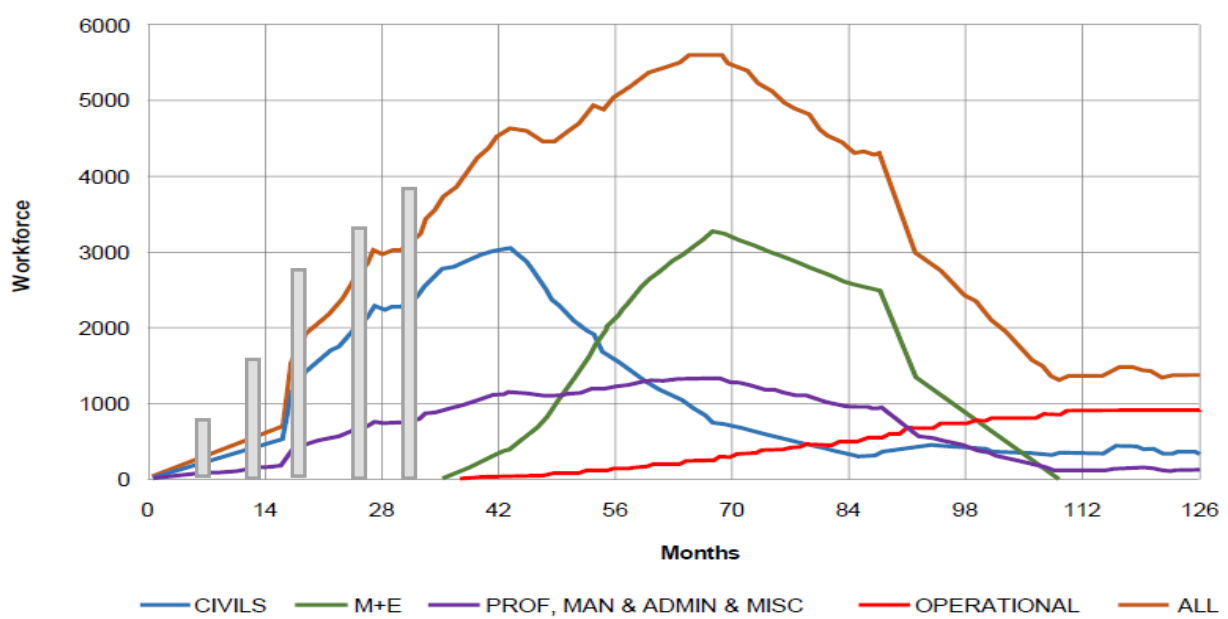

Figure 3: Actual local content percentage (cols) compared with predicted (curve), within the 90-minutes Construction Daily Commuting Zone (CDCZ)

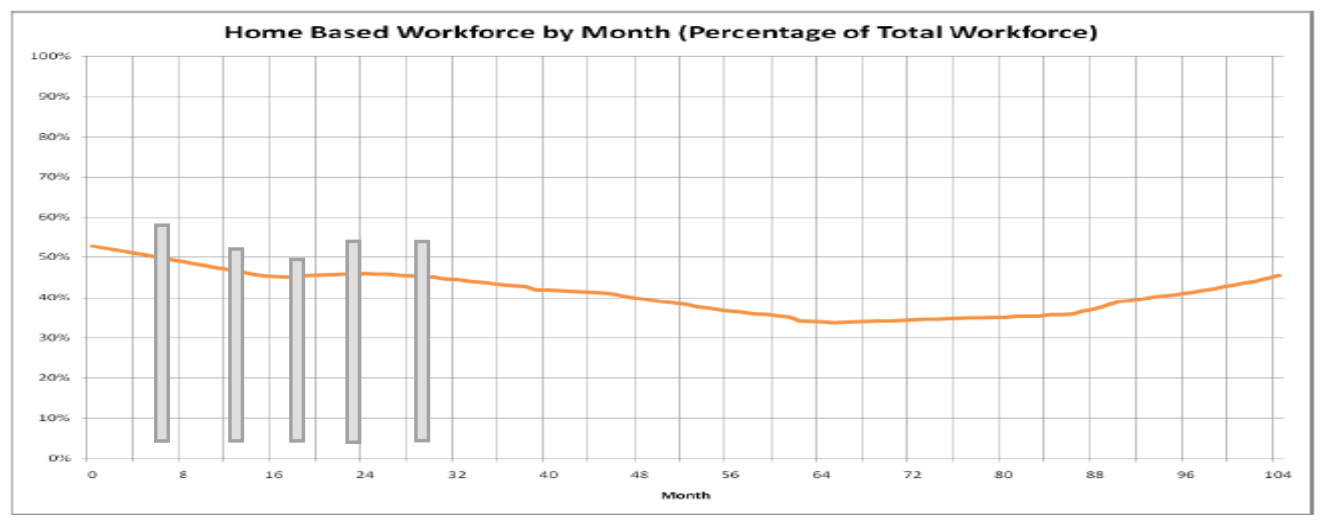

\subsection{Traffic and transport}

Table 6 shows that the Park and Ride (P\&R) provision, which switches workers from their cars at M5 junctions into buses to the site, is working well, with over $90 \%$ of workers using the scheme. However, the car share usage to the P\&R sites is below target, but hopefully this will improve with further promotion. HGV deliveries are also keeping to limits; for example, the Monday-Friday actuals are well below the daily limit of 750 vehicles. The unexpected traffic issue has been the impact of some of the travelling workforce fly parking, causing much disturbance to Somerset village communities. 


\begin{tabular}{|l|l|l|}
\hline Indicator/KPI & Examples of audited impacts & $\begin{array}{l}\text { RAG } \\
\text { Coding }\end{array}$ \\
\hline $\begin{array}{l}\text { Workforce - journey } \\
\text { to work to HPC site }\end{array}$ & $\begin{array}{l}\text { HPC Site Journey to Work by Bus has a target of 87\%. Since Q1 2017, } \\
\text { actual has been well over 90\% for each quarter. }\end{array}$ & $\mathbf{G}$ \\
\hline $\begin{array}{l}\text { Workforce - travel to } \\
\text { P\&R sites }\end{array}$ & $\begin{array}{l}\text { Travel to and from J23 and J24 dominated by single car drivers with } \\
\text { target of 58/60\% being consistently exceeded with up to 80/75\% } \\
\text { respectively at the P\&R sites. Promotion of HPC Car Share to meet } \\
\text { targets in hand. }\end{array}$ & R \\
\hline $\begin{array}{l}\text { HGVs - and } \\
\text { deliveries limits }\end{array}$ & $\begin{array}{l}\text { Consistent compliance with limits : Mon-Fri (750), Saturday (375) and } \\
\text { Quarterly Average (500) }\end{array}$ & G \\
\hline $\begin{array}{l}\text { HGV breaches of } \\
\text { construction works }\end{array}$ & $\begin{array}{l}\text { Breaches in terms of Heavy Goods Vehicle limits, timing restrictions, } \\
\text { routing violation have all been consistently in the very low single figures. }\end{array}$ & G \\
\hline
\end{tabular}

Table 6: Some examples of audited traffic and transport predictions

\subsection{Accommodation}

Table 7 provides a summary snapshot of some of the local accommodation impacts. These show a much more spatially concentrated distribution of inmigrant workers than predicted, especially in the town of Bridgewater, and proportionately many more in private rented accommodation than predicted. However, assessment here was complicated by fragmented sets of accommodation data; lack of monitoring against thresholds for the majority of the KPIs; and lack of availability of some data specific to the Construction Development Commuting Zone. Further, and of particular importance for this monitoring and auditing exercise, most of the accommodation predictions of the geographical distribution and tenure of the inmigrant construction workforce relate to peak construction employment; the project is not at that stage yet — and there are no intermediate predictions.

\begin{tabular}{|c|c|c|c|}
\hline Indicator/KPI & Examples of audited impacts & \multicolumn{2}{|c|}{$\begin{array}{l}\text { RAG } \\
\text { Coding }\end{array}$} \\
\hline $\begin{array}{l}\text { Geographical distribution } \\
\text { of inmigrant workers }\end{array}$ & Numbers/\% in Bridgewater well in excess of predictions & \multicolumn{2}{|c|}{$\mathbf{A}$} \\
\hline $\begin{array}{l}\text { Tenure type of } N H B \\
\text { workforce: } P R S\end{array}$ & $\begin{array}{l}\text { Jan } 2019 \text { numbers exceed predicted peak thresholds for } \\
\text { Bridgwater Initiatives in place to increase PRS capacity }\end{array}$ & \multicolumn{2}{|l|}{$\mathbf{A}$} \\
\hline $\begin{array}{l}\text { Tenure type of inmigrant in } \\
\text { tourist accommodation }\end{array}$ & Roughly near predictions & \multicolumn{2}{|l|}{ LG } \\
\hline $\begin{array}{l}\text { Tenure type of inmigrant } \\
\text { workforce in campuses }\end{array}$ & $\begin{array}{l}\text { Good use of on-site campus. Bridgewater campus only recently } \\
\text { completed. }\end{array}$ & $\begin{array}{l}\text { Site } \\
\text { G }\end{array}$ & $\begin{array}{l}\text { Brid } \\
\text { B }\end{array}$ \\
\hline $\begin{array}{l}\text { Implementation of EDFE } \\
\text { local housing support } \\
\text { strategy/ fund }\end{array}$ & $\begin{array}{l}\text { Many gaps in publicly available monitoring data/thresholds. } \\
\text { Available data suggests useful housing support initiatives. }\end{array}$ & \multicolumn{2}{|l|}{$\mathbf{A}$} \\
\hline
\end{tabular}

Table 7: Some examples of audited accommodation predictions 


\section{Explanation of findings}

The explanation of findings and differences between actual and predicted impacts for Hinkley Point $\mathrm{C}$ raises a number of positive and negative factors influencing impacts at this early stage in the ten-year construction programme. There are many positive findings, often resulting from the effective implementation of mitigation and enhancement measures and conditions. These for example include the transformational skills, training and education provision; the on-site campus with its high quality Medical Centre; and the Workers Code of Conduct and community safety initiatives. The purpose of the Code of Conduct is to set clear expectations for the social behaviour of workers when within the community. Transport initiatives include the Park and Ride facilities, the Cannington Bypass, and the bus to site system. There are also a whole array of management plans and, primarily developer (EDFE), funding initiatives.

Factors behind some of the more negative findings, and differences between actual and predicted impacts, can be grouped into a number of categories, as set out in Table 8 . The long delay between project consent and start of main construction had implications for the currency of baseline data for both the project and the local area. Some monitoring indicators lacked clarity, as did the timing of when certain mitigation measures should be in place (eg: late completion of temporary jetty into the Severn Estuary meant more heavy goods traffic by road to the site). A focus of predictions on peak construction also resulted in an absence of intermediate points in the construction stage for comparing actual and predicted; this was especially an issue for the accommodation sector.

In terms of process audit, the research also identified some weaknesses in the organisation and resourcing of the monitoring and auditing activities for the project, between the developer and the local authorities, which limited the effectiveness of the process for some impact sectors. Monitoring groups, and their activities, worked well for some sectors, for example for health and community safety, and for much of transport and employment, with a regular reporting of information against KPIs. For others, especially accommodation, organisation and data output was more fragmented and less useful for auditing purposes. There was no environment-monitoring group, and a dearth of publicly available information on environmental health and biophysical environmental impacts.

\begin{tabular}{|l|l|}
\hline $\begin{array}{l}\text { Time delays in } \\
\text { commencement of } \\
\text { construction project }\end{array}$ & $\begin{array}{l}\text { Major 5-year delay in commencement of main construction stage, with } \\
\text { predictions dated by at least 5 years. } \\
\text { The predictive data on the construction workforce requires a refresh against a } \\
\text { timeline to reflect a more adaptive impact assessment }\end{array}$ \\
\hline Project modifications & $\bullet \begin{array}{l}\text { For example, this includes delay in delivering a temporary jetty; provision of } \\
\text { only one Bridgwater Accommodation Campus; and revised s106 re level of } \\
\text { private rented accommodation; changes to delivery of various highway } \\
\text { improvement schemes; and construction programme changes in timing between } \\
\text { two reactor units. }\end{array}$ \\
\hline $\begin{array}{l}\text { Changes in baseline } \\
\text { conditions }\end{array}$ & $\begin{array}{l}\text { For example, includes: significant changes in local and regional unemployment } \\
\text { levels from the higher levels predicted in baseline studies to lower levels in } \\
\text { 2018/19. }\end{array}$ \\
\hline $\begin{array}{l}\text { Inadequate } \\
\text { organisation and } \\
\text { resourcing of the } \\
\text { monitoring and } \\
\text { auditing activities }\end{array}$ & $\begin{array}{l}\text { Fragmented monitoring arrangements between the developer and the local } \\
\text { authorities. } \\
\text { Absence of publicly available information on environmental health and } \\
\text { biophysical environmental impacts }\end{array}$ \\
\hline
\end{tabular}




\begin{tabular}{|l|ll|}
\hline & $\bullet \begin{array}{l}\text { Monitoring arrangements not explicitly secured in the Development Consent } \\
\text { Order/planning permission for the project. }\end{array}$ \\
\hline $\begin{array}{l}\text { Lack of clarity on } \\
\text { definition of some } \\
\text { indicators }\end{array}$ & $\begin{array}{l}\text { For example, for employment -- what is a worker, and which workers should be } \\
\text { included in the site profile? } \\
\text { Lack of targets for some indicators - for example, for several accommodation } \\
\text { indicators. }\end{array}$ \\
\hline $\begin{array}{l}\text { Lack of trigger points } \\
\text { in DCO/s106 } \\
\text { obligations and } \\
\text { requirements }\end{array}$ & $\begin{array}{l}\text { For example, lack of including, or delay in meeting, DCO trigger points in } \\
\text { relation to completion of temporary jetty, Bridgwater Campus accommodation, } \\
\text { and P\&R sites. }\end{array}$ \\
\hline $\begin{array}{l}\text { Failures of DCO examination to assess the robustness of the accommodation } \\
\text { strategy/s106. } \\
\text { construction impacts }\end{array}$ & $\begin{array}{l}\text { Whilst some sector predictions include evolution of impacts over the } \\
\text { construction stage (eg-- for employment local content), longitudinal timelines } \\
\text { are missing for other sectors (especially accommodation), leading to mismatch } \\
\text { between actual early construction (civils) stage and predicted peak impacts. }\end{array}$ \\
\hline $\begin{array}{l}\text { Degree of accuracy of } \\
\text { some predictive } \\
\text { techniques. }\end{array}$ & $\begin{array}{l}\text { For example -- concerns about effectiveness of gravity model approach in } \\
\text { forecasting local geographical distribution of inmigrant workforce. }\end{array}$ \\
\hline
\end{tabular}

Table 8: Some factors explaining differences between actual and predicted impacts

\section{Recommendations for monitoring and management practice}

There are many positive findings from the auditing of the early years of the HPC construction project, often resulting from the effective implementation of mitigation and enhancement measures and conditions. However, the findings also raise a number of issues. This section considers some specific recommendations for a refresh for the monitoring and auditing of the next phases of the HPC construction project, followed by an outline of generic recommendations for future NNB developments. The recommendations draw partly on the comparative practice case studies undertaken in the research.

For the current HPC project, there are many monitoring organisation and data recommendations. These include for example reviewing the operational effectiveness of the various monitoring groups. There is an urgent need for an environment-monitoring group and an improvement in the operation of the accommodation-monitoring group to optimise data opportunities. The London Crossrail project provides a good example of environmental monitoring (Crossrail 2018). The monitoring system also needs to deliver accurate and disaggregated employment information, especially on local content by skill category and by disadvantaged and under-represented groups. Similarly, the London Olympics project provides a good example of monitoring and auditing the impacts of the project construction on a wide range of population groups in London and beyond (ODA 2011). The developer, EDFE has responded positively to many issues and recommendations, including the initiation of a major review, in the spirit of adaptive environmental assessment and management, to consider the implications of a revised higher level of peak construction employment, and to update and refresh various strategies and plans, including those for accommodation, health and community safety. Changes are also in hand with the monitoring process in relation to key areas of employment and accommodation, and the introduction of an environment-monitoring group to cover physical environmental topics. 
Figure 4: Some interim recommendations -- Generic for future NNB and other large projects -- Preconstruction planning and assessment - primarily for developer (with LA involvement as appropriate)

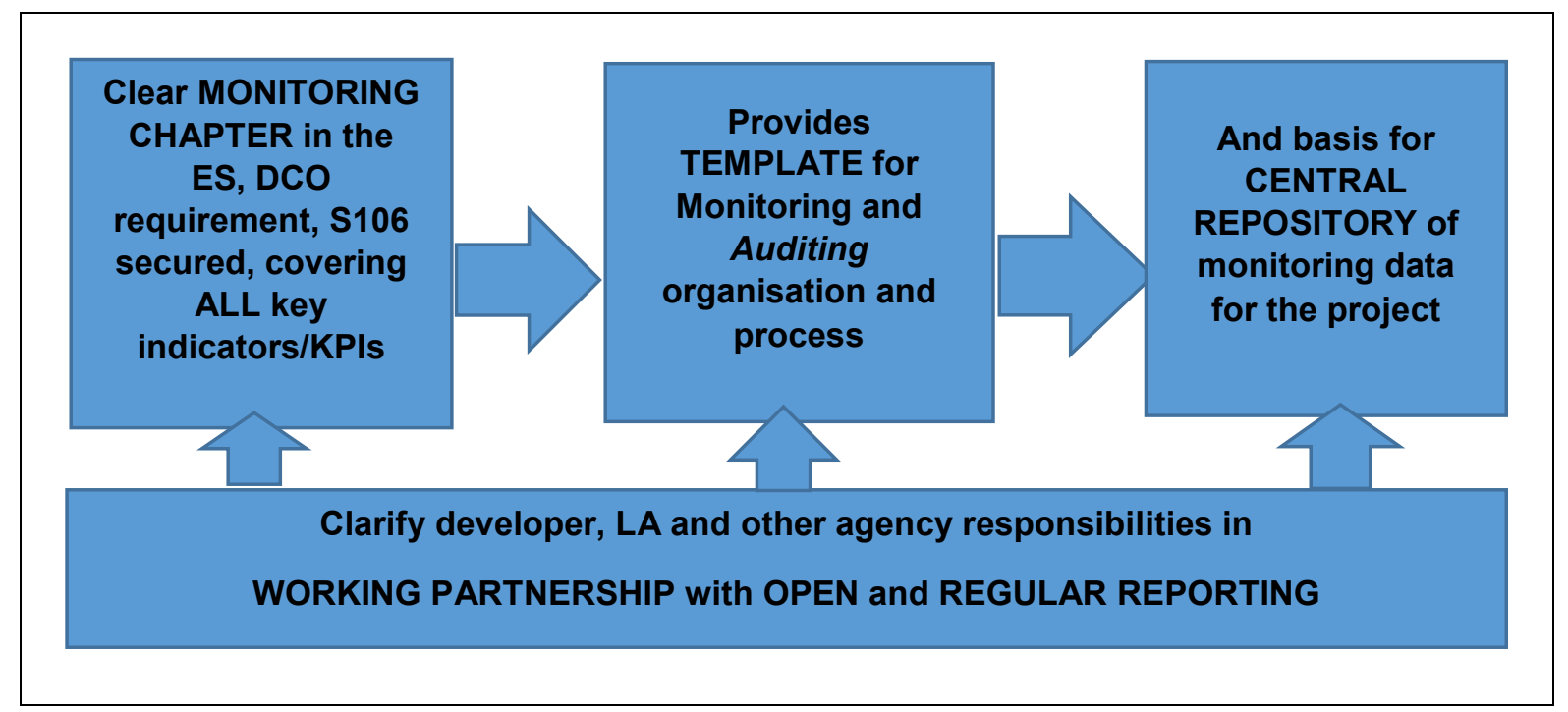

Figure 5: Some interim recommendations -- Generic for future NNB and other large projects Construction stage - primarily for developer (but with LA involvement as appropriate)

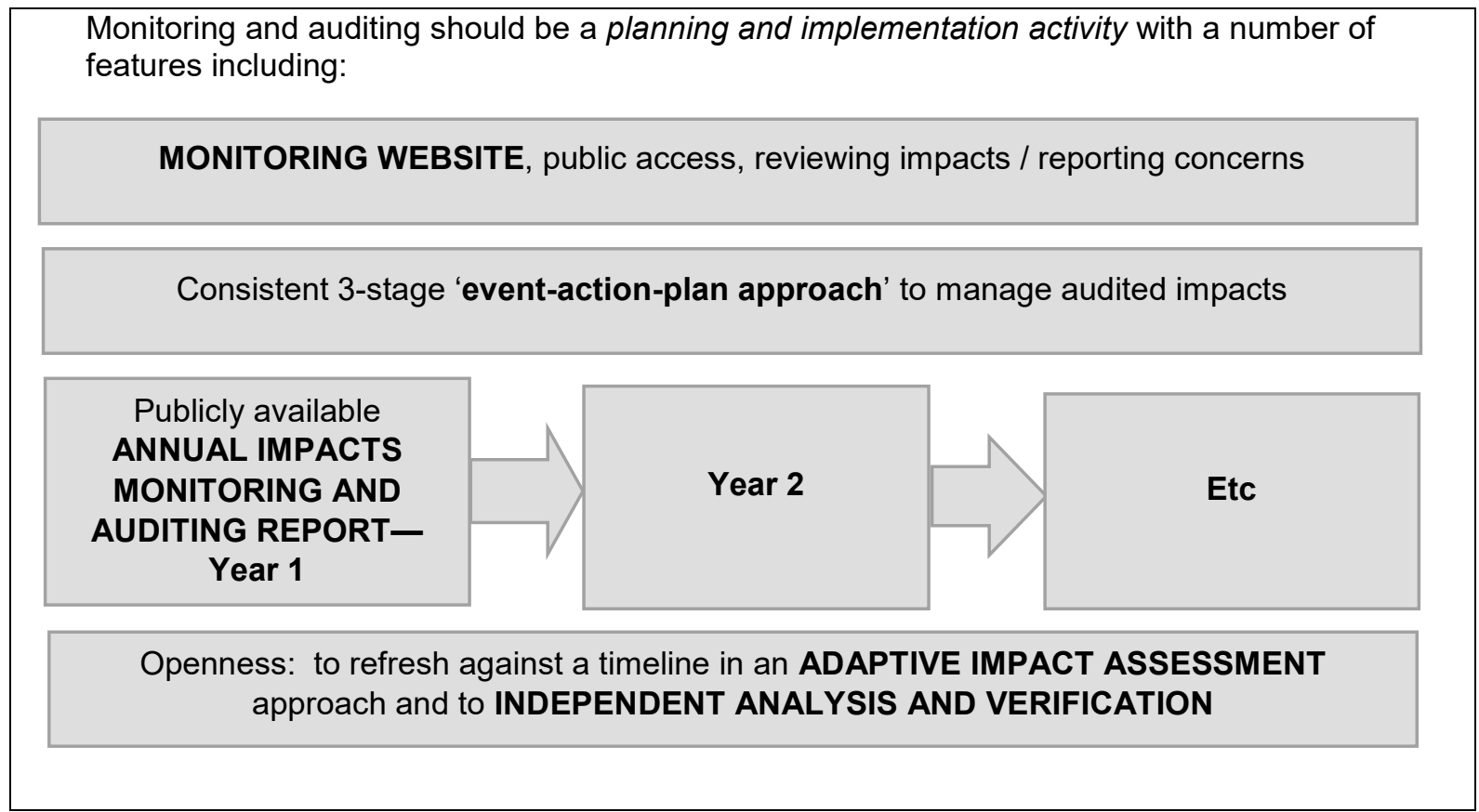

Some of the generic recommendations for future NNB, and other large developments more generally, are diagrammatically set out in Figures 3 and 4, distinguishing between the pre-construction planning 
and assessment stage and the construction stage. For example, for pre-construction there should be a monitoring chapter in the ES, referenced as a DCO requirement by the Examining Authority, which brings together the key indicators/KPIs across all the socio-economic and biophysical topic areas. This can provide the template for subsequent monitoring and auditing over the project lifecycle, and the basis for a central repository of monitoring data for the project. There should be service level agreements for local authorities to adequately monitor and report the wide-ranging impacts of the construction of major projects.

Recommendations for the construction stage include, for example, the production of a publicly available Annual Impacts Monitoring and Auditing Report. As for the current HPC system, there should be provision for Community Fora - but also for a Monitoring Website, with public access, and to which members of the public can report their concerns on project performance back to the developer and local authorities. A three stage 'event-action-plan' approach seeks to provide a more consistent approach to handling impact issues. This includes: (1) a trigger level to provide an early warning of problems; (2) an action level, at which action is taken before an upper limit of impacts is reached; and (3) a target level, beyond which a pre-determined plan response is initiated to avoid or rectify any problems.

The ES for the Wylfa Newydd proposed NNB in North Wales provides a good example of a project construction-monitoring framework, and a consolidated list of the developer's environmental and sustainability corporate policies for the project. It also provides a comprehensive listing of monitoring and reporting information outlined in the s106 with, for example, quite specific monitoring requirements for project supply chain and workforce accommodation data (Horizon Nuclear Power 2019).

\section{Conclusions}

Until the advent of the requirements and guidance under the revised EU EIA Directive (EU 2014, 2017) project monitoring and auditing were not mandatory in EU states. As noted earlier, even where there have been examples of regulatory requirements in some EU states, monitoring and auditing is limited in practice. In other cases, it may be that practice is ahead of regulation, with some enlightened developers and consultants realising some of the benefits of follow-up. However, certainly in the case of the UK, there is a dearth of detailed follow-up studies, especially for major projects. This situation should improve with the new regulations, adopted in UK EIA regulations (HMG 2017) --- even with the UK leaving the EU!

The HPC research provides an insight into the relationship between actual and predicted impacts across six key socio-economic and physical environment sectors of a major project. It also identifies some unforeseen events, and management responses. The prediction and compliance audits show that performance varies, but there are many examples of good outcomes, often reflecting the application of required mitigation and enhancement measures. Economic development findings show generally good predictions and compliance for workforce and supply chain impacts. Indeed, the enhancement measures for skills and training initiatives for the local employees have been quite transformative for the Somerset area. The outcomes to date for transport predictions, with mitigation measures, including the $P \& R$ system and coach transfer to site, have also been good, although the unexpected incidence of fly parking caused some serious community concern. There are also positive findings for many social and community impact areas. Mitigation measures, such as the on-site medical campus, and the Worker's Code of Conduct, have been effective at minimising negative impacts on the local NHS provision and on local community safety. 
In other areas, there are examples of differences between actual and predicted impacts. The accommodation predictions suffer in particular from a lack of predictions for key phases of the construction stage, leading to a mismatch between the actual early construction (civils work) phase and predicted peak construction phase impacts. Other determinants of mismatch between actual and predicted impacts across the sectors included for example, time delays in commencement of construction project, changes in baseline conditions, project modifications, and lack of clarity on definition of some indicators. For some areas, an absence of data limits judgement. This is the case for impacts on environmental health and the biophysical environment. Whilst there is good regulation of these impact areas in the UK, with various standards and thresholds, and with monitoring by the developer and relevant agencies, the researchers found little publicly available information to confirm this, other than a relatively low level of local complaints.

A process audit shows some strengths but also some weaknesses in the organisation and resourcing of the monitoring and auditing activities, between the developer and the local authorities for the construction stage of the HPC project. For example, in addition to the absence of a clear project group responsible for environmental monitoring, other organisational issues included the absence in several sectors of clear KPIs, irregular reporting of some indicators and a lack of a robust and consolidated approach to the monitoring exercise, as set out in the ES and reviewed in the examination process. The research recommendations indicate some ways of improving monitoring and auditing practice, both for this project and for future NNB and major projects more widely. These include, for example for preconstruction, the importance of a monitoring chapter in the ES, referenced as a DCO/ planning permission requirement by the examining authority, bringing together the key indicators/KPIs across all the socio-economic and biophysical topic areas. This can then provide a template for subsequent monitoring and auditing in the construction stage and beyond, and for a publicly accessible repository of project impact data.

From such findings, we regard the Hinkley Point $\mathrm{C}$ construction stage auditing and monitoring research as a particularly useful and timely study, which can provide pointers for hopefully more and better monitoring and auditing activity. It is a mega-construction project, with wide ranging impacts. It is a live and ongoing project; there are implications for future stages of the long HPC construction cycle. In addition, the plan is for HPC to be the first of a new generation of UK NNB projects, and there are lessons for those projects. Indeed, stakeholders are already using the findings of the research in the planning and assessment for the next UK NNB project, at Sizewell C in East Anglia (EDFE, 2020). The findings and recommendations are also relevant to major projects more generally. The identify, monitor and audit approach, and the RAG colour coding of findings, provided a logical research approach that was clearly understandable for the stakeholders involved. There were some challenges in the approach, especially in sifting through a mass of ES, Management Plans and Local Impact Reports documentation to identify key indicators, some of which changed over time, and in finding monitoring information for some sectors as noted. At this stage, the plan is for the research team to revisit the project, and such challenges, around peak construction, in a further stage of monitoring and auditing, as part of an adaptive assessment process.

\section{Notes}

${ }^{1}$ Development Consent Order (DCO) is the term used under the 2008 Planning Act in England for the 'planning permission' associated with Nationally Significant Infrastructure Projects (NSIPs), such as energy, transport, water and waste projects..

${ }^{2}$ A Section 106 (s106) is a legal agreement between an applicant seeking planning permission and the local planning authority, which is used to mitigate the impact of the project on the local community and infrastructure. 


\section{Acknowledgements}

The authors wish to acknowledge the funding support of the New Nuclear Local Authorities Group (NNLAG) for the Hinkley Point C monitoring and auditing study. NNLAG is a Local Government Association (LGA) Special Interest Group, consisting of fifteen Local Authorities from across the UK that already host or are likely to host nuclear new build projects. NNLAG's purpose is for local authorities to share knowledge, information and best practice regarding new nuclear, and to provide a mechanism for local authorities, as elected representatives of local areas, to discuss and make representations direct to Government regarding the development of new nuclear and of nuclear-related connection/transmission projects. NNLAG's member local authorities are Allerdale Borough Council, Isle of Anglesey County Council, Copeland Borough Council, Cumbia County Council, East Suffolk Council, Essex County Council, Lancaster City Council, Maldon District Council, Sedgemoor District Council, Folkestone \& Hythe District Council, Somerset County Council, South Gloucestershire Council, Suffolk County Council, and Somerset West \& Taunton Council. Particular thanks are due to members of the NNLAG Steering Group for the research: Michael Moll (Suffolk CC), Gillian Ellis-King (S. Gloucestershire DC), Andy Coupe (Somerset CC), Guy Kenyon (Cumbria CC), and Tom Day (Essex CC).

The authors also wish to acknowledge their appreciation of the contributions of the anonymous referees to the improvement of the article.

\section{References}

Arts, J., Caldwell, P and A. Morrison-Saunders 2001. EIA follow-up: good practice and future directions findings from a workshop at the IAIA 2000 Conference. Impact Assessment and Project Appraisal, 19(3), 175185.

Bjorkland, R 2013. Monitoring: the missing piece. A critique of NEPA monitoring. Environmental Impact Assessment Review 43, 129-134.

Chadwick, A. \& J. Glasson 1999. Auditing the Socio-Economic Impacts of a Major Construction Project: The Case of Sizewell B Nuclear Power Station. Journal of Environmental Planning and Management 42(6), 811-36.

Crossrail Ltd 2018. Good Practice Documents: Environmental Dashboards. London: Crossrail.

Culhane, PJ 1993. Post-EIS Environmental Auditing: A First Step to Making Rational Environmental Assessment a Reality. The Environmental Professional 15 (1 ), 66-75.

EDFE 2011. Hinkley Point C Environmental Statement, London: EDFE.

EDFE 2020. Sizewell C Environmental Statement, London: EDFE.

EU 2014. Directive 2011/92/EU, as amended by Directive 2014/52/EU, on the assessment of the effects of certain public and private projects on the environment. Brussels: EU.

EU 2017. EU Guidance on the preparation of the Environmental Impact Assessment Report (EIAR). Brussels: EU.

Glasson, J and A, Chadwick 1995. Local socio-economic impacts of the Sizewell B PWR Construction Project. Oxford: Oxford Brookes University, Impacts Assessment Unit.

Glasson, J 2005. 'Better monitoring for better impact management: the local socio-economic impacts of constructing Sizewell B nuclear power station', Impact Assessment and Project Appraisal, July .

Glasson, J and R Therivel 2019, Introduction to Environmental Impact Assessment: $5^{\text {th }}$ Edition --Chapter 7 Monitoring and Auditing: After the Decision. New York: Routledge.

Glasson, J, Durning, B, Broderick, M and K. Welch 2020 Study on the impacts of the early stage construction of the Hinkley Point C (HPC) Nuclear Power Station: Monitoring and Auditing Study Final Report. Available from the Oxford Brookes University repository https://doi.org/10.24384/xeb3-7x48

HMG 2017.The Infrastructure Planning (Environmental Impact Assessment) Regulations 2017SI No. 572 
Highways England 2016. Post Opening Project Evaluation (POPE) of Major Schemes: Meta Analysis 2015. Guildford: Highways England.

Holling, C, S (ed) 1978 Adaptive environmental assessment and management. New york: Wiley.

Horizon Nuclear Power 2019. https://www.horizonnuclearpower.com/our-sites; Accessed: 11/06/2019

IAPA (Impact Assessment and Project Appraisal) 2005,Special issue on EIA Follow-up, Impact Assessment and Project Appraisal, 23 (3)

Jones, R. and T. Fischer 2016. EIA follow-up in the UK-A 2015 update. Journal of Environmental Assessment Policy and Management, 18(1), 1-22

Marshall, R 2005. EIA follow-up and its benefits for industry. Impact Assessment and Project Appraisal, 23 (3) $191-196$

Marshall, R, Morrison-Saunders, A, and J. Arts 2005 EIA follow-up: international best practice principles. Impact Assessment and Project Appraisal, 23 (3) 175-181..

Morrison-Saunders, A, and J. Arts 2004 (editors), Assessing Impact: Handbook of EIA and SEA Follow-up, London: Earthscan.

NIPA (2019). Towards a Flexibility Toolkit: Supporting the delivery of better National Infrastructure Projects.NIPA Insights Project Board.

Olympics Delivery Authority 2011. Employment and skills update:Jan 2011. London:ODA.

Pinto, E, Morrison-Saunders, A , Bond, A and F. Reteif 2019 Distilling and Applying Criteria for Best Practice EIA Follow-up, Journal of Environmental Assessment Practice and Management, July

Planning Inspectorate 2013 No. 648 INFRASTRUCTURE PLANNING, The Hinkley Point C (Nuclear Generating Station) Order 2013 Made - - 18th March 2013; Coming into force - - 9th April 2013; plus s106 DCO documentation (Aug 2012).

Runhaar, H, van Laerhoven, F, Driessen, P and J, Arts 2013. Environmental assessment in the Netherlands: is it effectively governing environmental protection? A discourse analysis. Environmental Impact Assessment Review, $39,13-25$.

Somerset Councils 2012 Local Impacts Report (LIR) Appendix B2 Accommodation and Housing. Somerset: SCC, WSC and SDC.

IAPA - in press October 2020 